\title{
Terras de Cavaleiros Geopark: A UNESCO Global Geopark
}

\author{
Diamantino Insua Pereira and Paulo Pereira
}

\begin{abstract}
The Terras de Cavaleiros Geopark (TCG), a UNESCO Global Geopark, is located in Northern Portugal and is established on rare and unique geological, scenic, ecological and cultural values. The most significant geological value is related to the most complete sequence of Pre-Mesozoic allochthonous geological units in NW Iberia. The Vilariça fault is an important geomorphological feature in the TCG related to the evolution of landforms such as push-up blocks and strike-slip basins. Forty-two geosites were selected in the TCG, 16 of them being of geomorphological interest. A set of programs, including cultural heritage, biodiversity and leisure, has been prepared for scientific, educational and touristic use.
\end{abstract}

\section{Keywords}

Geopark • Allochthonous complex • Fault • Geosite • Geotourism

\subsection{Introduction}

The Terras de Cavaleiros Geopark (TCG) or The Land of Knights Geopark covers an area of $699 \mathrm{~km}^{2}$ corresponding to the administrative limits of the Macedo de Cavaleiros municipality in northern Portugal (Fig. 25.1). The TCG was established in recognition of rare and unique geological, scenic, ecological and cultural values. The local geology and geomorphology have a well-documented scientific value and

D. I. Pereira $(\square)$

Terras de Cavaleiros UNESCO Global Geopark,

Macedo de Cavaleiros, Portugal

e-mail: insuad@dct.uminho.pt

D. I. Pereira $\cdot$ P. Pereira

Institute of Earth Sciences, Pole of the University of Minho,

Braga, Portugal

e-mail: paolo@dct.uminho.pt long tradition in research and scientific visits. The Geopark territory is also nationally recognized for having a significant range of traditional quality products with national certification (olive oil, sausage, ham, cheese, potatoes, olives, chestnuts, honey and veal and lamb meat, among others). In addition, there are several reference sites for tourism, as the Azibo Reservoir, with a beach ranked as the best lake beach of Portugal, or the Sabor Valley, where visitors can enjoy landscape diversity with floristic richness and unique fauna.

The Terras de Cavaleiros Global Geopark project is ongoing since 2010, promoting geological and environmental conservation, social justice and sustained economic development for the territory and its inhabitants. The tourism is based on scenic, geological, ecological, cultural, historical and local identity values, pointing out what is authentic and unique (Pereira et al. 2013).

Within the Geopark, a detailed inventory and assessment of 42 geosites were accomplished. Seven of them are already listed in the national geosites inventory, which justifies their higher national and/or international significance (Pereira et al. 2012). Sixteen geosites were selected based on the geomorphological and tectonic features.

\subsection{Geological Setting}

The TCG is located in the Iberian Massif, the largest morphotectonic unit of the Iberian Peninsula, which is composed of pre-Mesozoic units consolidated during the Variscan orogeny. In many cases, the bedrock includes relics that have allowed the definition of the geological aspects preceding that cycle (Ribeiro 2013). The Iberian Massif is the westernmost segment of the European Variscan orogen (560-245 Ma), with which it was connected before the opening of the Bay of Biscay, between 110 and $75 \mathrm{Ma}$. The territory of TCG has a rich and complex geology (Fig. 25.2), mainly expressed in the following geological units (Pereira 2006a; Pereira et al. 2012): 


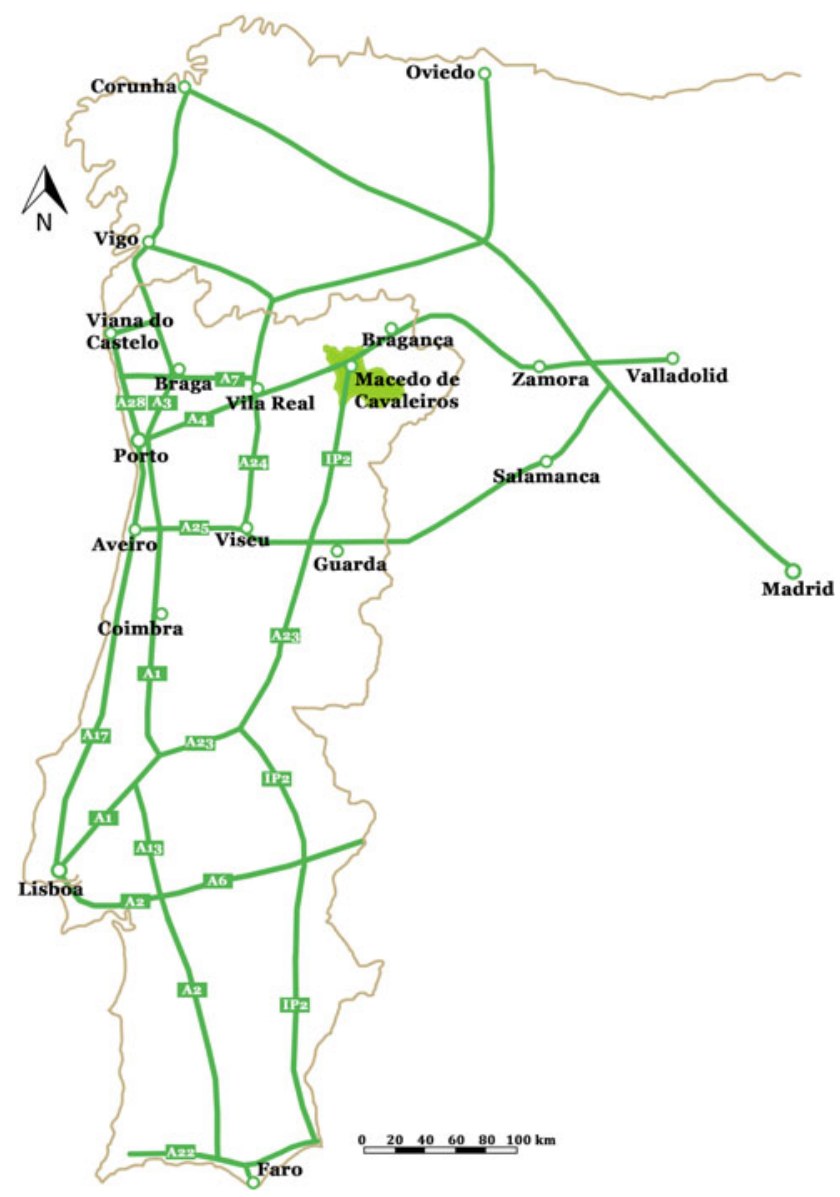

Fig. 25.1 Location of Terras de Cavaleiros Global Geopark in Northern Portugal

- Pre-Mesozoic allochthonous geological units,

- Variscan granitoids,

- Cenozoic sediments.

\subsubsection{Pre-Mesozoic Allochthonous Geological Units}

The Pre-Mesozoic allochthonous geological units are composed by the:

- Parautochthonous Complex, a unit that moved a few miles and shows paleogeographic affinities with the Central Iberian Zone, with schists, greywackes and quartzites as the most representative lithologies.

- Allochthonous Basal Complex, a unit that moved more than $100 \mathrm{~km}$ over the Parautochthonous Complex and is

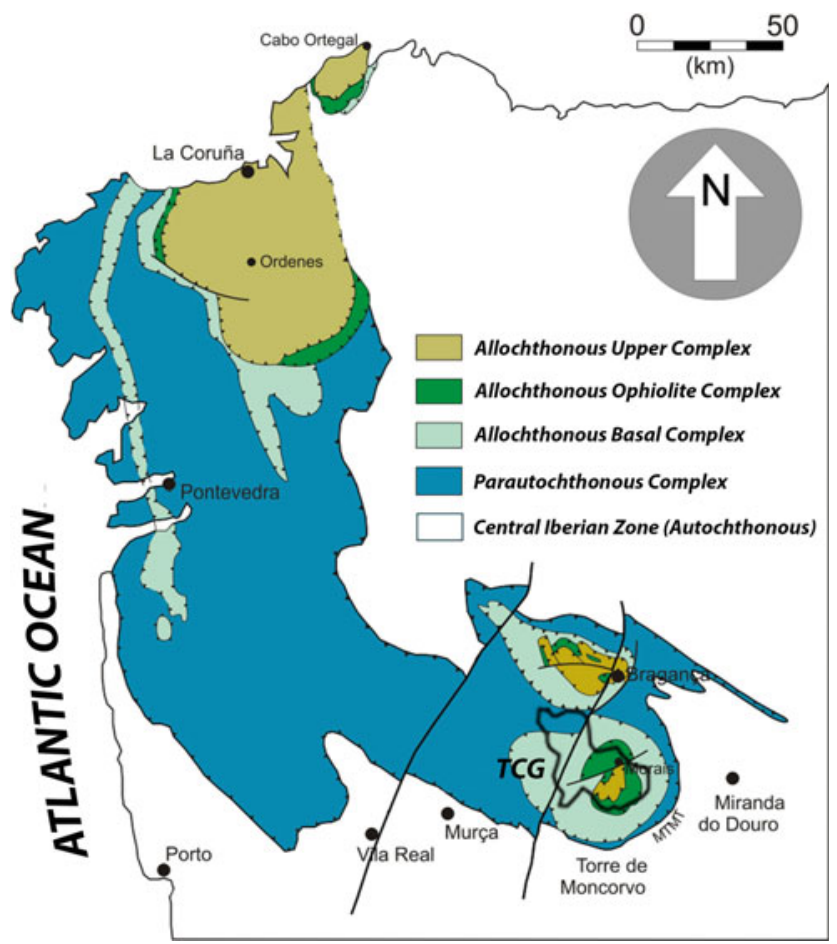

Fig. 25.2 Location of the Terras de Cavaleiros UNESCO Global Geopark in the framework of the Allochthonous Complexes of NW Iberia [adapted from Ribeiro et al. (1990), Pereira et al. (2012)]

representative of the Gondwana continent, showing metavolcanic rocks, schists and quartzites.

- Allochthonous Ophiolitic Complex, a complete sequence of the oceanic crust constituted by several types of mafic and ultramafic rocks. This ophiolite sequence results from the obduction of oceanic lithosphere over the Allochthonous Basal Complex. The ocean corresponded to the south branch of the Rheic Ocean, known as the Galiza/ Trás-os-Montes - Central Massif Ocean. The complete Ordovician to Devonian oceanic crust sequence comprises, from top to bottom, amphibolites, complexes of dykes, flaser gabbros, gabbros, mafic cumulates and ultramafic rocks with the generic designation of peridotites.

- Allochthonous Upper Complex, representing a whole sequence of continental crust from an ancient continent located far away from the autochthonous domain. This complex is represented by metasediments, orthogneisses and mafic and ultramafic rocks. It represents a complete sequence of continental crust derived from a distant margin, relatively to the autochthonous domain. Presumably, this complete fragment of continental crust had its origin at the Armorica microplate, a continental 
fragment independent from the north of Gondwana (Ribeiro et al. 2007).

Thus, one of the most complete and continuous sections of the Variscan chain in the Iberian Peninsula is represented in the TCG. The Allochthonous Ophiolitic Complex and the Allochthonous Upper Complex, as well as the thrust faults that mark the contacts between the units, are particularly well represented at the core of the TCG, known as the Morais Massif.

\subsubsection{Variscan Granitoids}

Some igneous rocks occur in the TCG, cutting the metasedimentary and metavolcanic units mentioned above. Beyond the veins, mostly of quartz, different granitoid facies may be distinguished, such as two-mica granites, muscovite granite and granodiorites. These granitoids are contemporary of the Variscan Orogeny and show a clear relation with the third orogenic phase, ranging between the so-called syn-D3 and post-D3 (Noronha et al. 2006).

\subsubsection{Cenozoic Sediments}

The sedimentary units that fill strike-slip basins and paleovalleys in the western border of the Cenozoic Douro Basin are well represented in the TCG. Up to the 1990s, these sediments had been systematically included in the so-called Iberian Raña facies, a gravelly deposit with significant coverage in the Douro Basin and also in the Iberian Massif. Raña refers to an alluvial fan model, chronologically placed near the Plio-Pleistocene limit, an episode related to the transition from the endorheic drainage of the Cenozoic Iberian basins to the present Atlantic drainage. More detailed investigations on these sediments (Pereira 1997, 1998, 1999, 2006a; Pereira et al. 2000) have revealed a fluvial network in the proximal sector of the Douro Basin and diverse tectonosedimentary units as described below (Pais et al. 2012).

The Bragança Formation (Upper Miocene to Lower Pliocene) is defined in north-eastern Portugal as a lithostratigraphic unit recording a proximal fluvial paleodrainage to the Cenozoic Douro Basin in Spain (Pereira 1997, 1998, 1999; Pereira et al. 2000). The fluvial sediments fill incised paleovalleys in response to two tectonic episodes and the consequent orogenic uplift. These paleovalleys remain well preserved in TCG (Vale da Porca, Salselas and Castro Roupal outcrops), where they are oriented E-W, and to the east, near Vimioso (Vimioso outcrop) and Miranda do Douro (Silva, Sendim and Atenor outcrops), where they are oriented NW-SE and N-S, respectively. Given the context of the major Vilariça fault, the fluvial system was strongly influenced by the development of strike-slip basins (De Vicente et al. 2011; Pais et al. 2012), especially in the TCG.

The Bragança Formation comprises two members with similar composition and depositional architecture. An unconformity based on the recognition of a regional erosion surface and a well-developed paleosoil occurs. Deep channel gravel deposits and gravelly bars are the most characteristic lithofacies of the Bragança Formation. The sediments are immature and contain moderately weathered feldspars in the sand fraction and a predominance of smectite and kaolinite in the clay fraction. The gravel units are mostly red in colour with lutite being brown, grey or green.

Geomorphological features suggest that prior to the deposition of the Bragança Formation river valleys incised in the bedrock developed as an erosional response to mountain uplift occurring since the Eocene (Pereira et al. 2000; De Vicente et al. 2008, 2011). Subsequently, the activity of this major tectonic episode, which corresponds to the Betic compression at about 9.5 Ma (Calvo et al. 1993), caused a staircase organization of large fault blocks in northern Portugal and the development of strike-slip basins associated with the Vilariça fault detachment (Ferreira 1991; Cabral 1995).

The Aveleda Formation (Upper Pliocene to Lower Pleistocene) is located in two different geomorphological settings: i. occurrences surrounding the TCG lie over the North Iberian Plateau, which marks a discontinuity with the older units, and have its source on the resistant reliefs; ii. occasionally, the unit lies within tectonic depressions associated with the Vilariça fault (Pereira 1997), especially in the TCG. The Aveleda Formation consists of reddish deposits mainly of muddy matrix-supported gravel. Clasts of several metasedimentary rocks and quartz are subangular. Kaolinite and illite dominate the clay fraction. The lithofacies and architecture of the Aveleda Formation indicate nearby sources and debris flows deposited as alluvial fan bodies. The unit establishes the transition between the previous endorheic drainage network and the Atlantic fluvial network (Pereira 2006b).

\subsection{Geomorphology}

The TCG area consists mostly of small plateaus, with altitudes between 700 and $800 \mathrm{~m}$ asl, and the Bornes and Nogueira mountains reaching 1200 and $1300 \mathrm{~m}$ asl. These push-up compressive structures are related to a major faultoriented NNE-SSW and showing neotectonic activity-the Vilariça fault. Associated with it, several small strike-slip basins filled with Cenozoic sediments occur (Pereira and Pereira 2019). The deeply carved Sabor River defines the eastern limit of the TCG. West of the fault, the drainage is 


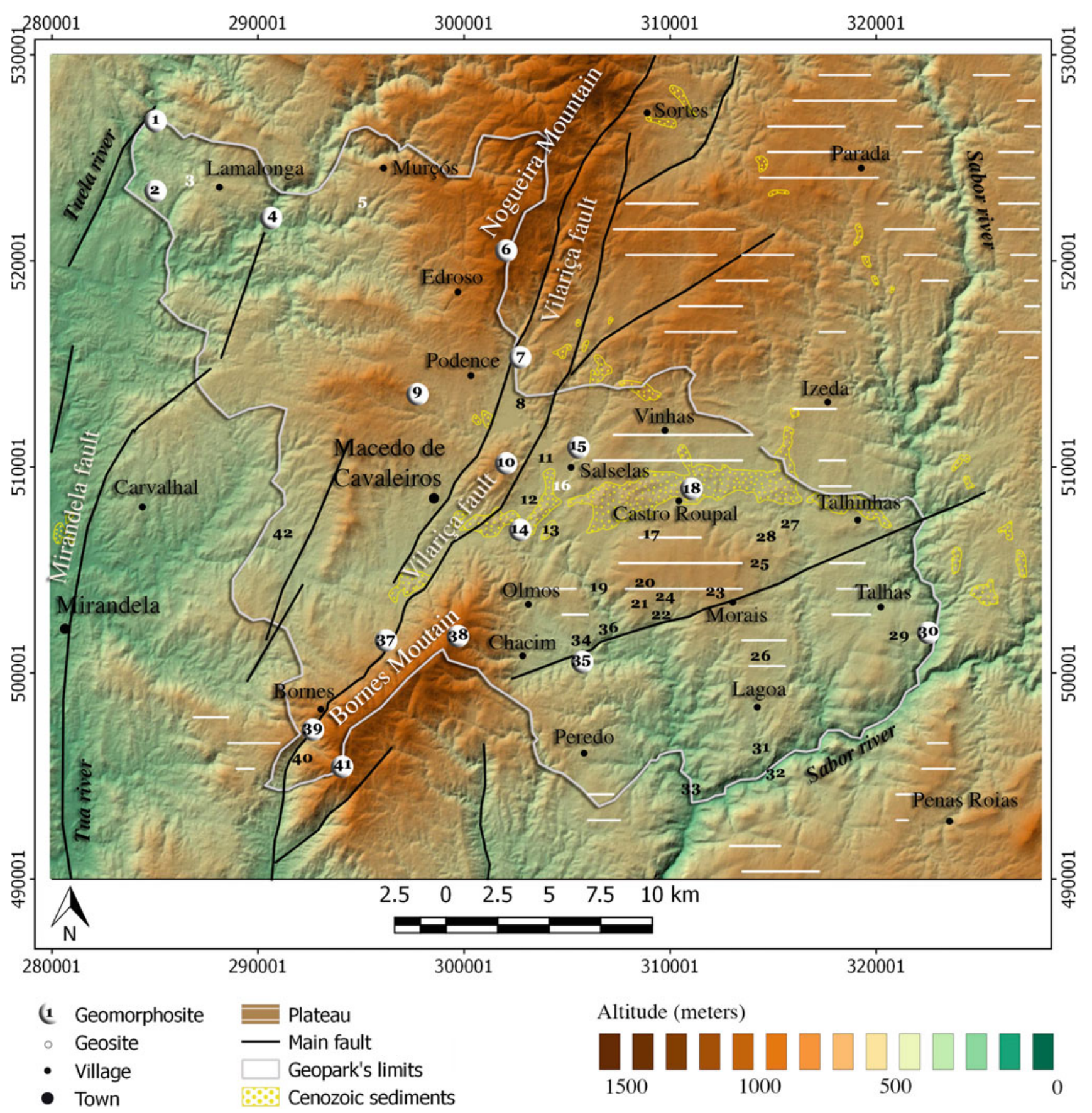

Fig. 25.3 Simplified geomorphological map of the Terras de Cavaleiros UNESCO Global Geopark

towards the Tua River (Fig. 25.3). The Sabor and Tua sub-catchments are part of the Douro River catchment, one of the largest Iberian rivers, which has its mouth in Oporto.

The regional significance of the Vilariça fault is widely recognized in studies of the landscape of northern Portugal (e.g. Cabral 1995; De Vicente et al. 2008, 2011; Pais et al. 2012). This strike-slip fault has great morphological expression in the TCG, through several strike-slip basins such as the Santa Combinha, Macedo de Cavaleiros and Vilariça basin to the south, as well as uplifted compressive structures in a push-up model, like the Bornes and Nogueira mountains (Cabral 1995; Pereira 1997, 2006). In the NW sector of the TCG, the south flank of the Nogueira Mountain stands out, reaching an altitude of $1231 \mathrm{~m}$ in the Pombares Massif granites. This NNE-SSW tectonic block is located to the west of the main branch of the Vilariça fault. In the south, the Bornes Mountain $(1,200 \mathrm{~m}$ asl) stands out as a tectonic relief, oriented NNE-SSW, parallel to the Vilariça fault 


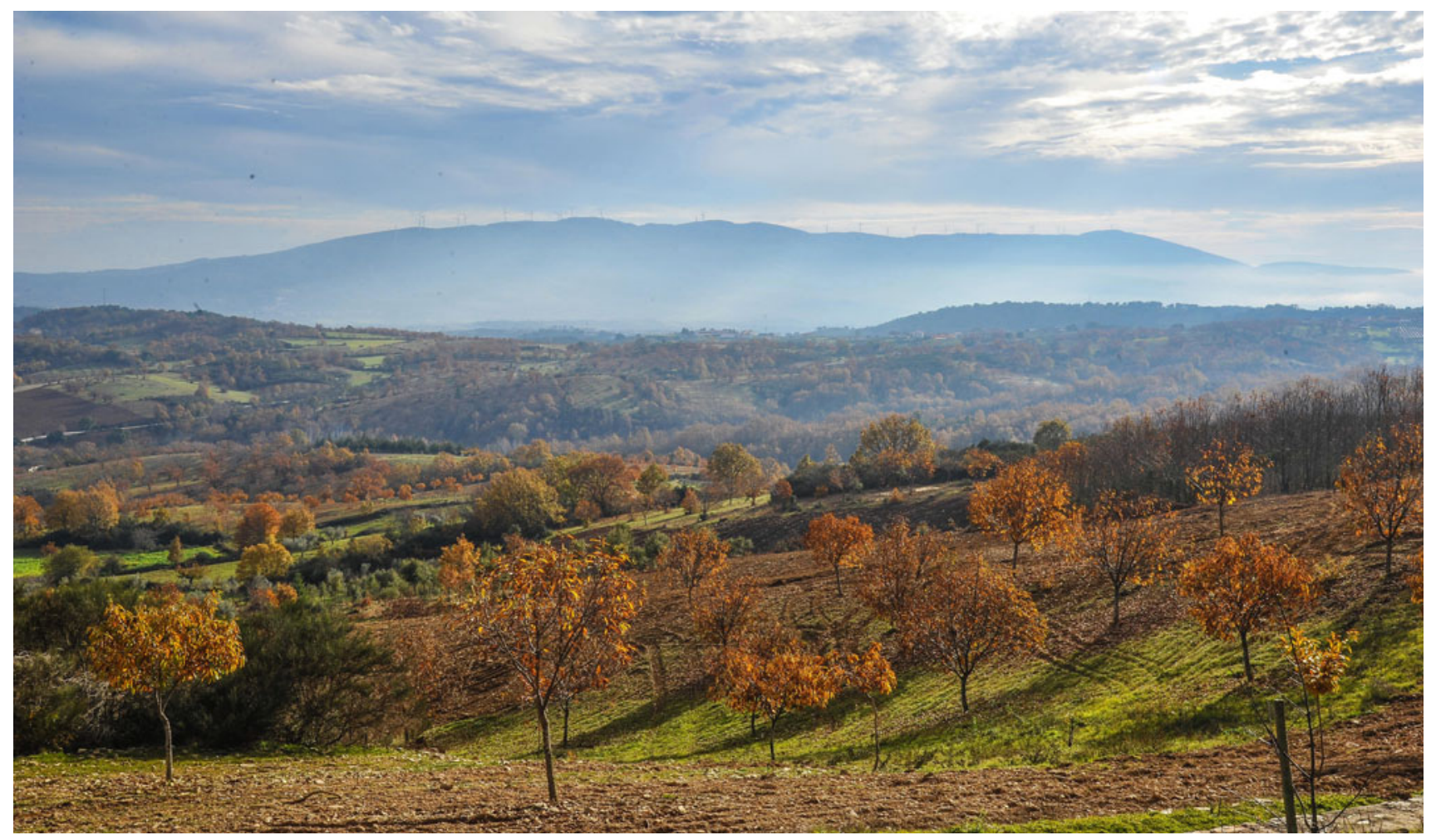

Fig. 25.4 Bornes Mountain, limited by the Vilariça fault, view from the Senhora do Campo geosite

(Figs. 25.3 and 25.4). In the southern limit of the TCG, the $\mathrm{N}-\mathrm{S}$ fault scarp extends to the Vilariça depression.

Regionally, the Vilariça fault constitutes also the limit between the eastern sector, where the fundamental surface of the North Iberian Plateau (Meseta) is more regular, and the western sector where the fundamental surface is extensively dissected by the Douro fluvial network (Fig. 25.3). The regular flattish surface of the Morais Massif occurs to the north of the Morais fault, about $750 \mathrm{~m}$ asl and is representative of the North Iberian Plateau, also known as North Iberian Meseta. This surface, well preserved in the Morais Massif, represents a reference to the interpretation of all other regional surfaces. Portions of the same surface are also preserved to the north and east.

North of the Morais Massif, the Vale da Porca-Talhinhas depression is oriented E-W and $150 \mathrm{~m}$ below the fundamental surface. This depression is one of the paleovalleys that preserve sediments of the Bragança Formation, associated with a previous fluvial system flowing eastwards towards the Douro Cenozoic Basin, mentioned above (Fig. 25.5).

The NE-SW depression of Macedo de Cavaleiros is limited between faults of the Vilariça tectonic zone and preserves alluvial fan sediments of the Aveleda Formation. The fact that the Macedo de Cavaleiros tectonic depression is drained towards the Tuela River by the Macedo and the
Carvalhais tributaries is a noteworthy peculiarity that shows the tectonic control of the drainage system. The remaining territory lies within the Sabor Basin. The Sabor River, bordering the Geopark in the east, shows steep slopes and is incised about $400 \mathrm{~m}$ in the plateau (Fig. 25.6). The tributary streams also show deep valleys, except when crossing tectonic depressions.

In the western sector of the TCG, some planation surfaces are slightly lowered relative to the regular level of the plateau, which is due to differential uplift and subsidence. These surfaces are tectonic steps connecting to the Mirandela depression (Fig. 25.3).

\subsection{Geosites}

The selection of geosites in Terras de Cavaleiros Geopark was primarily focused on their scientific value. After the first identification of potential geosites, 42 were selected as effective geosites, based on a qualitative assessment. The selected geosites represent mineralogical, petrological, structural, geomorphological and hydrogeological themes. Sixteen geosites are specifically related to geomorphological and tectonic features (Table 25.1, Fig. 25.3).

For geotouristic and general touristic support, the TCG promoted the selection of geosites after an assessment of 


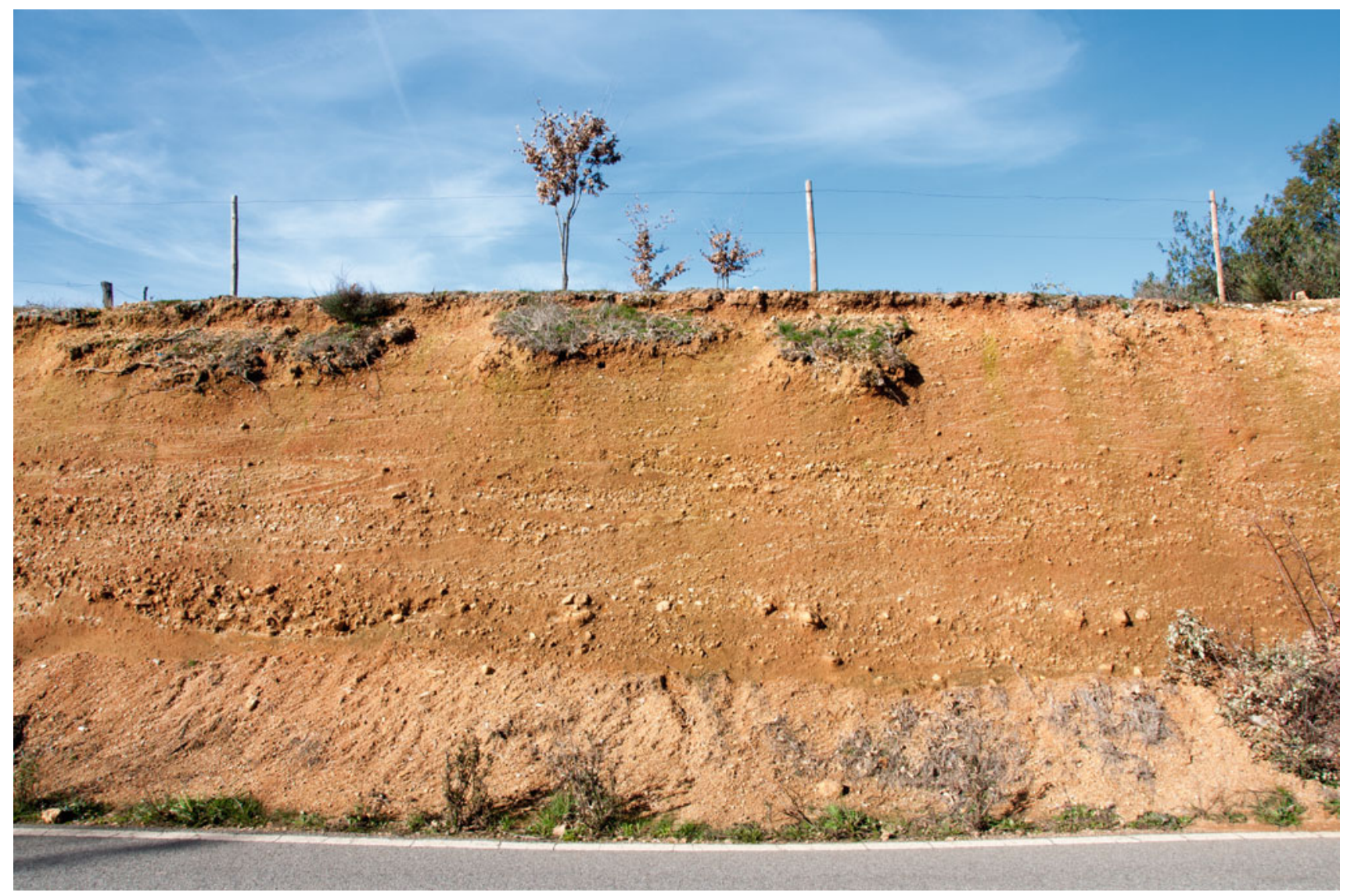

Fig. 25.5 Sediments of the Bragança Formation filling the Vale da Porca-Talhinhas paleovalley (Castro Roupal geosite)

touristic interest. These geosites, which always show scientific value, also stand out for their cultural, economic and/or scenic values. In addition to the geoconservation and management issues, its valuation includes outreach with simplified explanations. Some of the TCG most representative geosites are described below.

\subsubsection{Geomorphosites}

\section{(a) Senhora do Campo geosite}

The Senhora do Campo geosite is an exceptional place to observe and understand the most significant features of the regional landscape, in particular (Fig. 25.7): (i) the surface of the Morais Massif, representing an isolated portion of the North Iberian Plateau, a planation surface, well-known and also recognized in other regions, (ii) the Nogueira and the
Bornes mountains, which are tectonic landforms associated with the Vilariça fault, (iii) the Mogadouro Mountain, on the horizon, an excellent example of residual landform standing out from the plateau and (iv) the Azibo River valley carved in the plateau.

\section{(b) Cabeço Berrão geosite}

Cabeço Berrão geosite is a panoramic viewpoint to the deep incision of the Sabor River in the North Iberian Plateau (Fig. 25.6). In addition to the geomorphological value, the site presents cultural interest due to the presence of ruins of a fortification attributed to the Iron Age, in which local rocks were used, namely amphibolites, schists and gabbros.

\section{(c) Bornes South geosite}

The Bornes South geosite is a panoramic viewpoint located on the southwest slope of the Bornes Mountain, from where landforms connected to the Vilariça fault can be observed. 


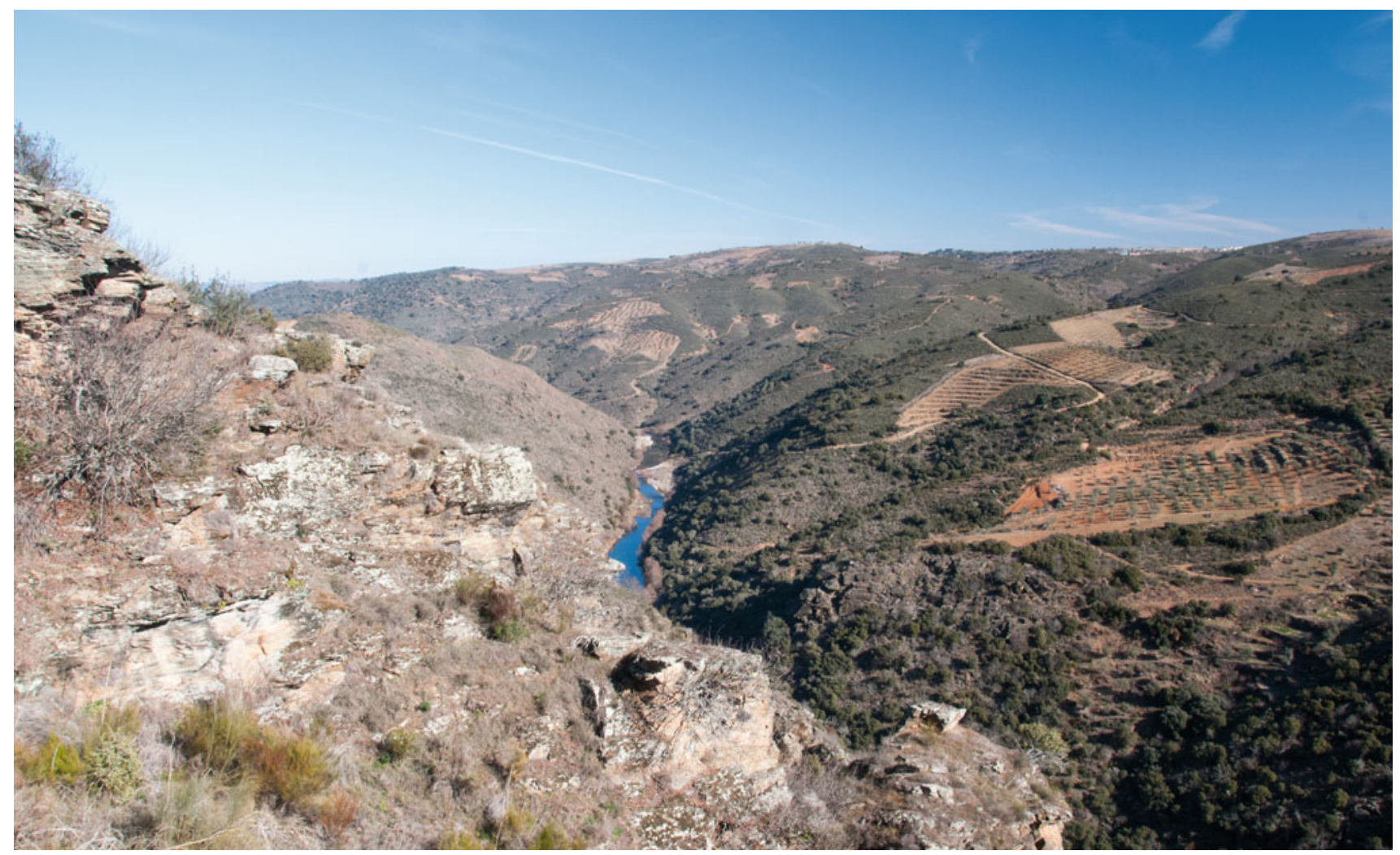

Fig. 25.6 Sabor River deeply carved in the North Iberian Plateau, view from Cabeço Berrão geosite

The fault produces well-defined scarps and controls the Burga River course in a straight-lined valley (Fig. 25.8). Further to the south, the Vilariça strike-slip basin (Pereira and Pereira 2019) can also be seen from here.

\section{(d) Vilariça fault gouge at Podence geosite}

The Podence geosite is the best place to perceive the Vilariça fault at an outcrop-scale (Fig. 25.9). The vertical fault gouge, about $10 \mathrm{~m}$ wide, places metavolcanic rocks of the ancient bedrock (Silurian) in contact with Cenozoic sediments (Gelasian), testifying the recent movement of the fault.

\subsubsection{Other Geosites}

\section{(a) Conrad and Moho discontinuities geosite}

The Conrad and Moho discontinuities geosite is an important spot in TCG, where ophiolite and allochthonous processes associated with the Variscan orogeny can be interpreted. The geosite includes the tectonic contact between the Earth's upper continental crust (represented by the Lagoa gneiss), the lower continental crust (represented by the granulite), and the mantle (represented by the peridotite). The geosite location offers a panoramic view to the thrusted geological units differentially eroded in the opposite slope of the Sabor River valley (Fig. 25.10).

\section{(b) Foz do Azibo thrust fault geosite}

At the Foz do Azibo geosite, the tectonic stacking of the main geological units involved in the Variscan orogeny can be seen. It is possible to interpret the Armorica continent (represented by the Lagoa gneiss) overlapping the remains of the Paleozoic Rheic Ocean (represented by the amphibolite) (Fig. 25.11).

\section{(c) Poço dos Paus geosite}

The Poço dos Paus geosite combines scientific and scenic values of the Azibo valley, with the visitor being encouraged to observe rocks typical of the ocean floor (Fig. 25.12). The 
Table 25.1 Main features of the 16 geosites with geomorphological interest (geomorphosites) in the TCG territory

\begin{tabular}{|c|c|c|}
\hline Reference & Geosites & Main geological features \\
\hline G1 & Tuela valley & 300 m deep canyon in the Tuela River \\
\hline G2 & $\begin{array}{l}\text { Torre de Dona Chama } \\
\text { granite }\end{array}$ & Granite boulders and other typical granite landforms \\
\hline G4 & Macedo river meanders & Meanders of the river Macedo canyon controlled by N-S faults \\
\hline G6 & Alto da Serra granite & Typical granite landforms like tor and castle kopje \\
\hline G7 & $\begin{array}{l}\text { Vilariça fault gouge at } \\
\text { Podence }\end{array}$ & Vilariça fault with a significant $10 \mathrm{~m}$ wide fault gauge \\
\hline G9 & $\begin{array}{l}\text { Senhora do Campo } \\
\text { panorama }\end{array}$ & $\begin{array}{l}\text { A panoramic site to observe the major Bragança-Vilariça-Manteigas fault alignment, the Azibo } \\
\text { Reservoir, the Morais Massif and the North Iberian Plateau }\end{array}$ \\
\hline G10 & Cubo panorama & A $360^{\circ}$ panorama of the TCAG showing the main landforms \\
\hline G14 & $\begin{array}{l}\text { Vale da Porca Cenozoic } \\
\text { sediments }\end{array}$ & Cenozoic sediments affected by small faults as evidence of neotectonic events \\
\hline G15 & Salselas tectonic basin & Small basin filled with sediments is an example of a geomorphological feature with tectonic control \\
\hline G18 & $\begin{array}{l}\text { Castro Roupal } \\
\text { palaeovalley }\end{array}$ & Cenozoic sediments representing an ancient drainage system with cross-bedded stratification \\
\hline G30 & $\begin{array}{l}\text { Cabeço Berrão } \\
\text { panorama }\end{array}$ & Panorama over the Sabor River canyon \\
\hline G35 & Morais fault & ENE-WSW fault with neotectonic activity \\
\hline G37 & $\begin{array}{l}\text { Vilariça fault at Vale } \\
\text { Bemfeito }\end{array}$ & $\begin{array}{l}\text { Breccia of the Vilariça fault with fragments of granites, quartz and boulders of the cenozoic } \\
\text { sediments }\end{array}$ \\
\hline G38 & Bornes North panorama & Panorama over the general geomorphology of the Geopark area \\
\hline G39 & $\begin{array}{l}\text { Vilariça fault scarp at } \\
\text { Burga }\end{array}$ & Panoramic site to observe the geomorphological expression of the Vilariça fault scarp \\
\hline G41 & Bornes South panorama & Panorama over the Vilariça strike-slip basin \\
\hline
\end{tabular}

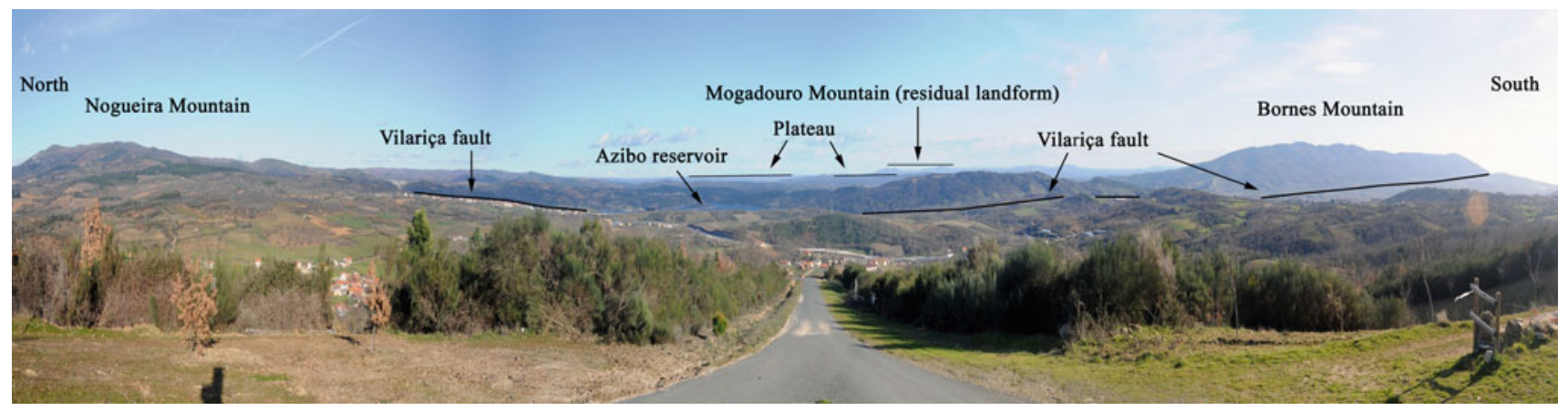

Fig. 25.7 Main landforms observed in the Senhora do Campo geosite

site shows mafic dikes in bands of dark colour, that broke through gabbro, showing light and dark minerals of larger dimensions. A simplified explanation of when and how the rocks were formed and on their exotic condition is presented on-site.

\section{(d) Lagoa Gneiss geosite}

Lagoa Gneiss geosite has high scientific and scenic values. The approach is based on the beauty of the gneiss in the outcrop (Fig. 25.13), its exotic nature attending to its origin hundreds of kilometres away and the doubt about the exact age of this occurrence. The outcropping also preserves very clear kinematic criteria that constitute a precious element for the geodynamic reconstitution of the Variscan orogeny in Iberia.

\section{(e) Murçós Mine geosite}

The Murçós mine geosite is dedicated to several outcrops of an open-air mine and to the ruins of support buildings separation of the ore took place between 1940 and 1980. This 


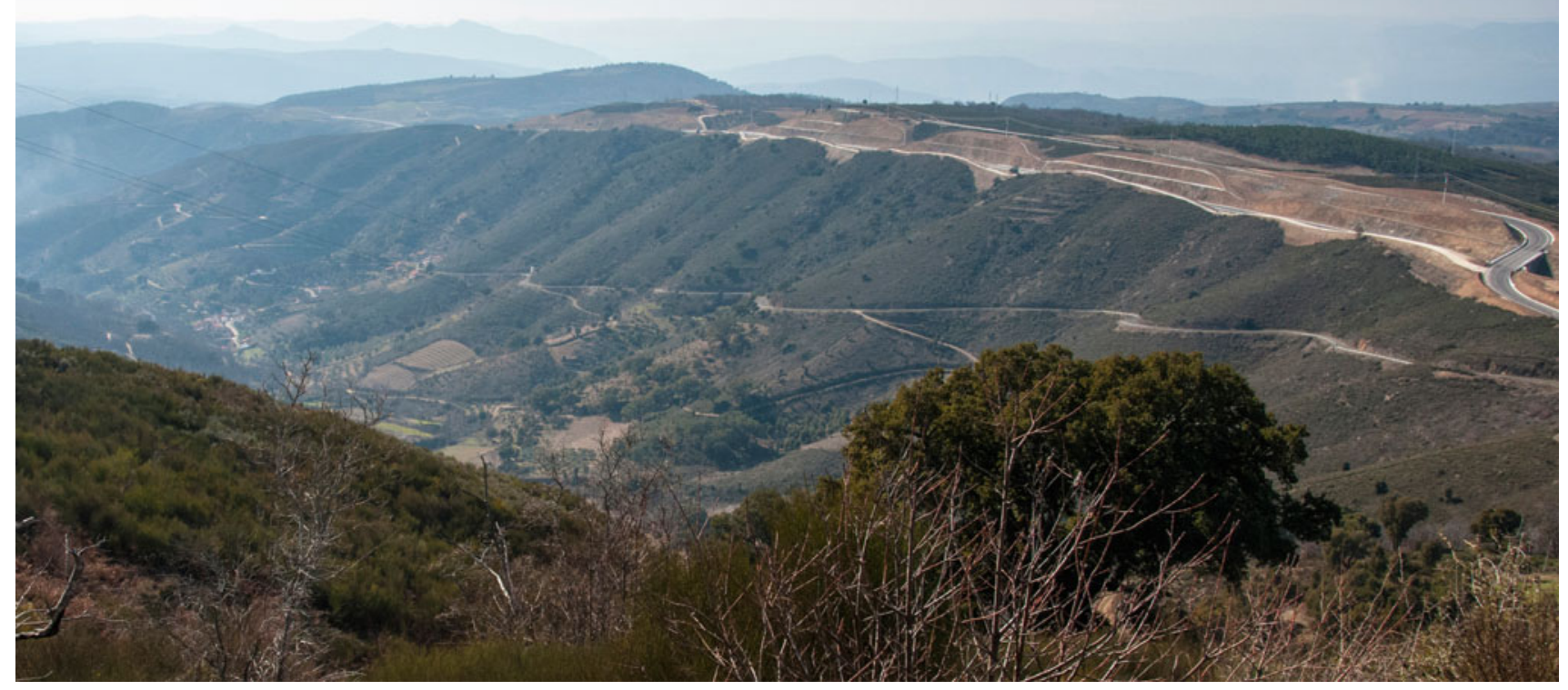

Fig. 25.8 Panoramic view to the south at the Bornes South geosite, where the Burga River valley is controlled by the Vilariça fault

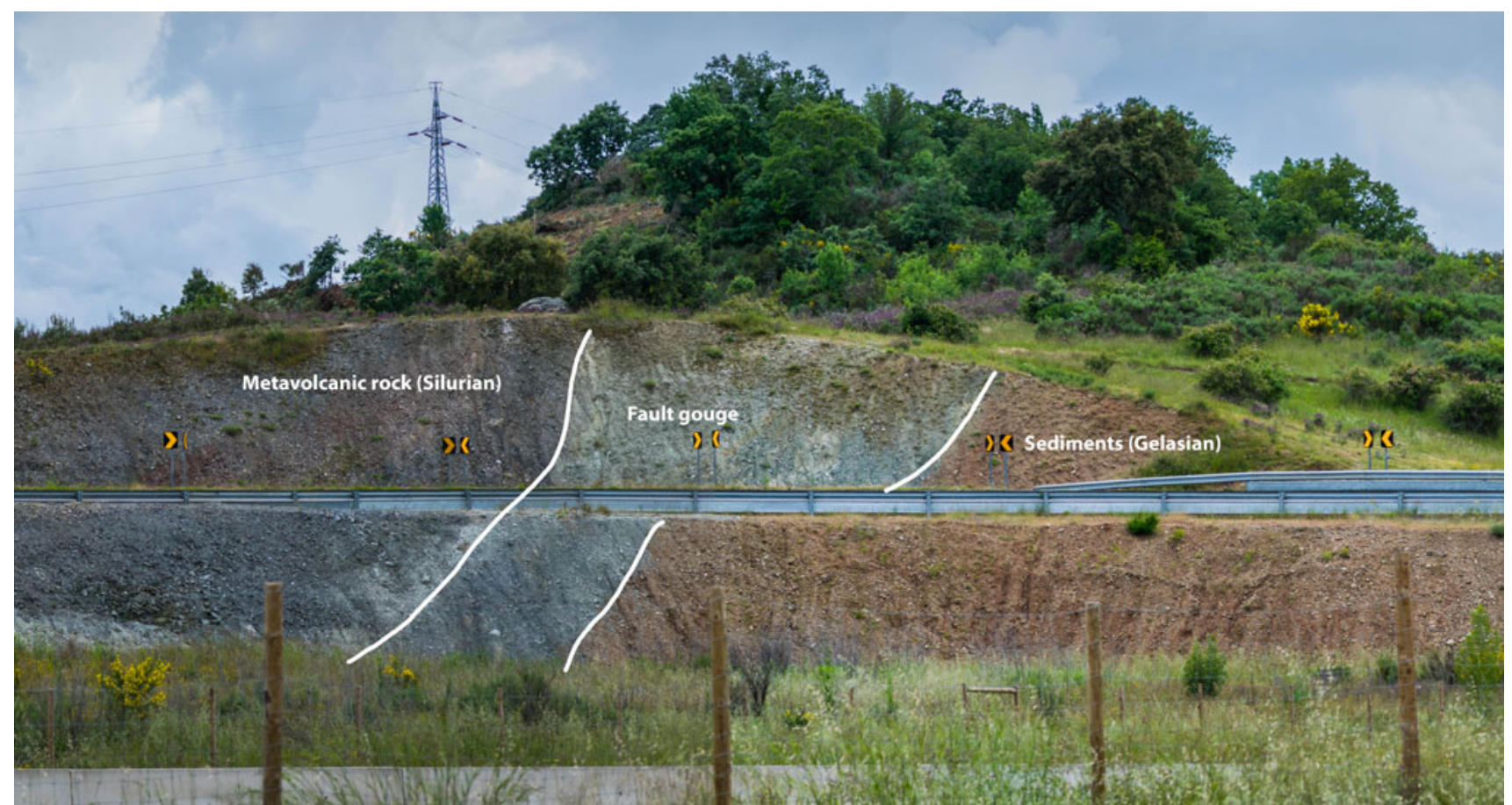

Fig. 25.9 Vilariça fault gouge at the Podence geosite 


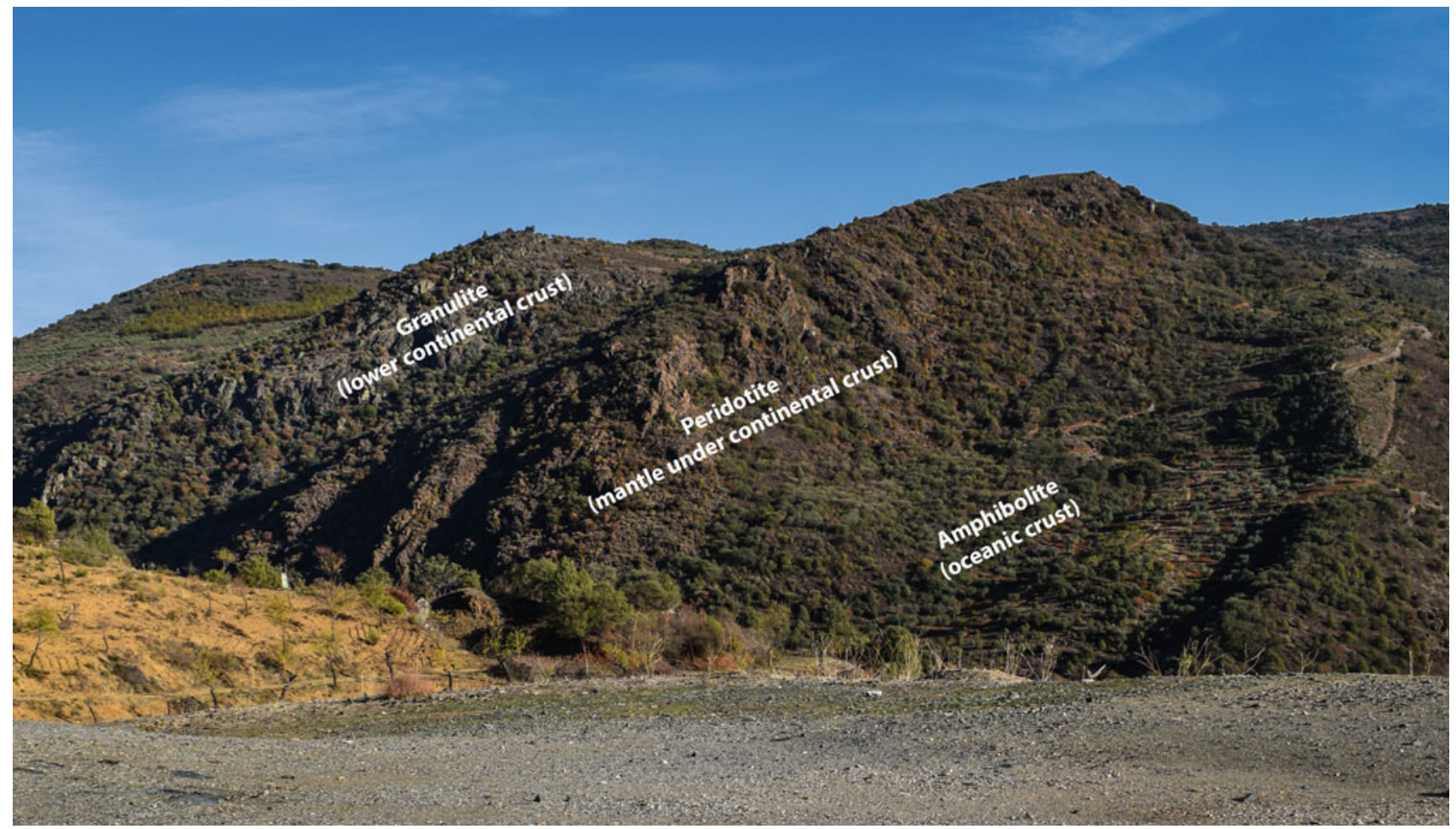

Fig. 25.10 Panoramic view from the Conrad and Moho discontinuities geosite, to the thrusted geological units in the opposite slope of the Sabor River valley, where differential erosion occurs

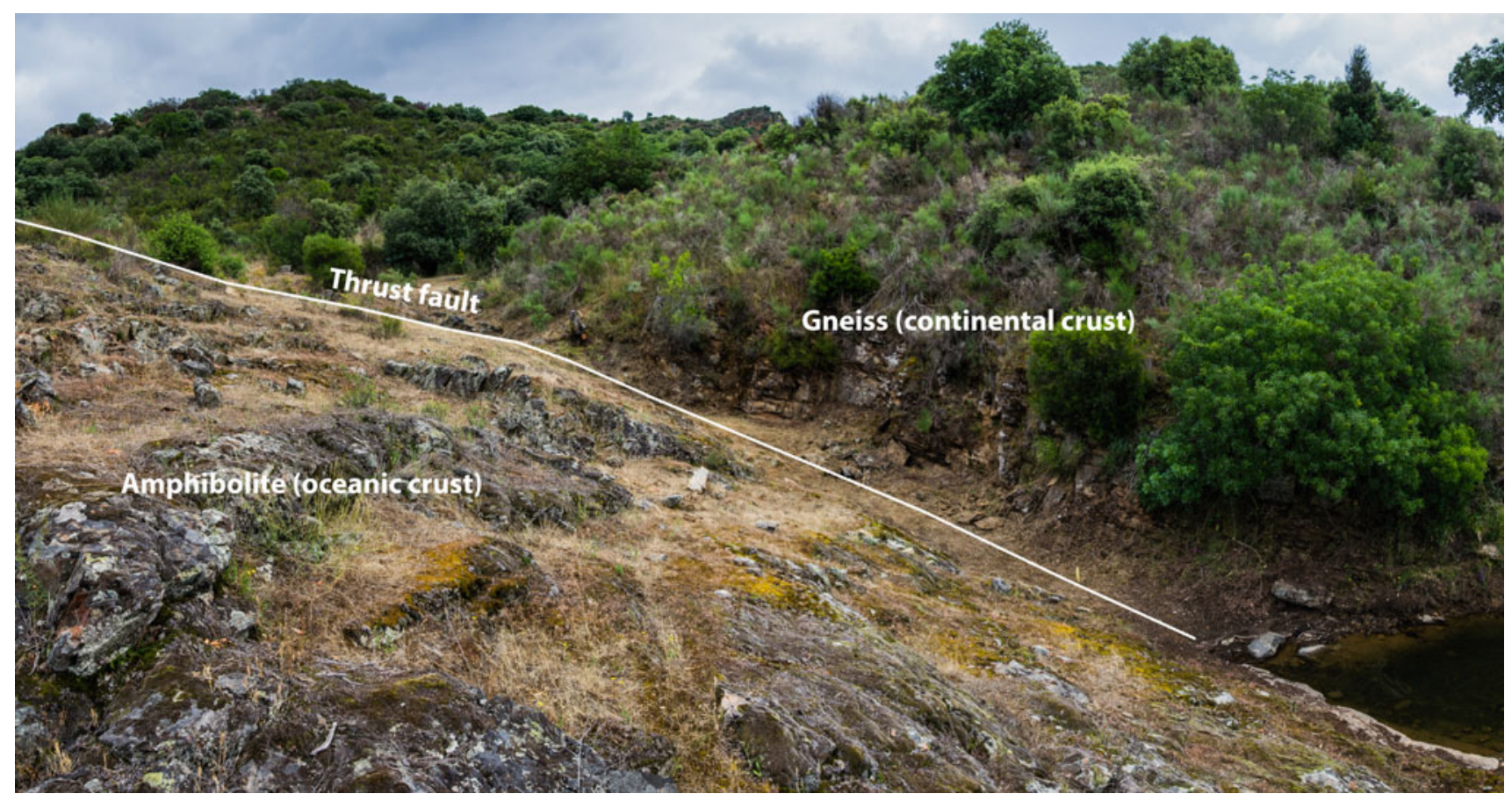

Fig. 25.11 Foz do Azibo thrust fault geosite 


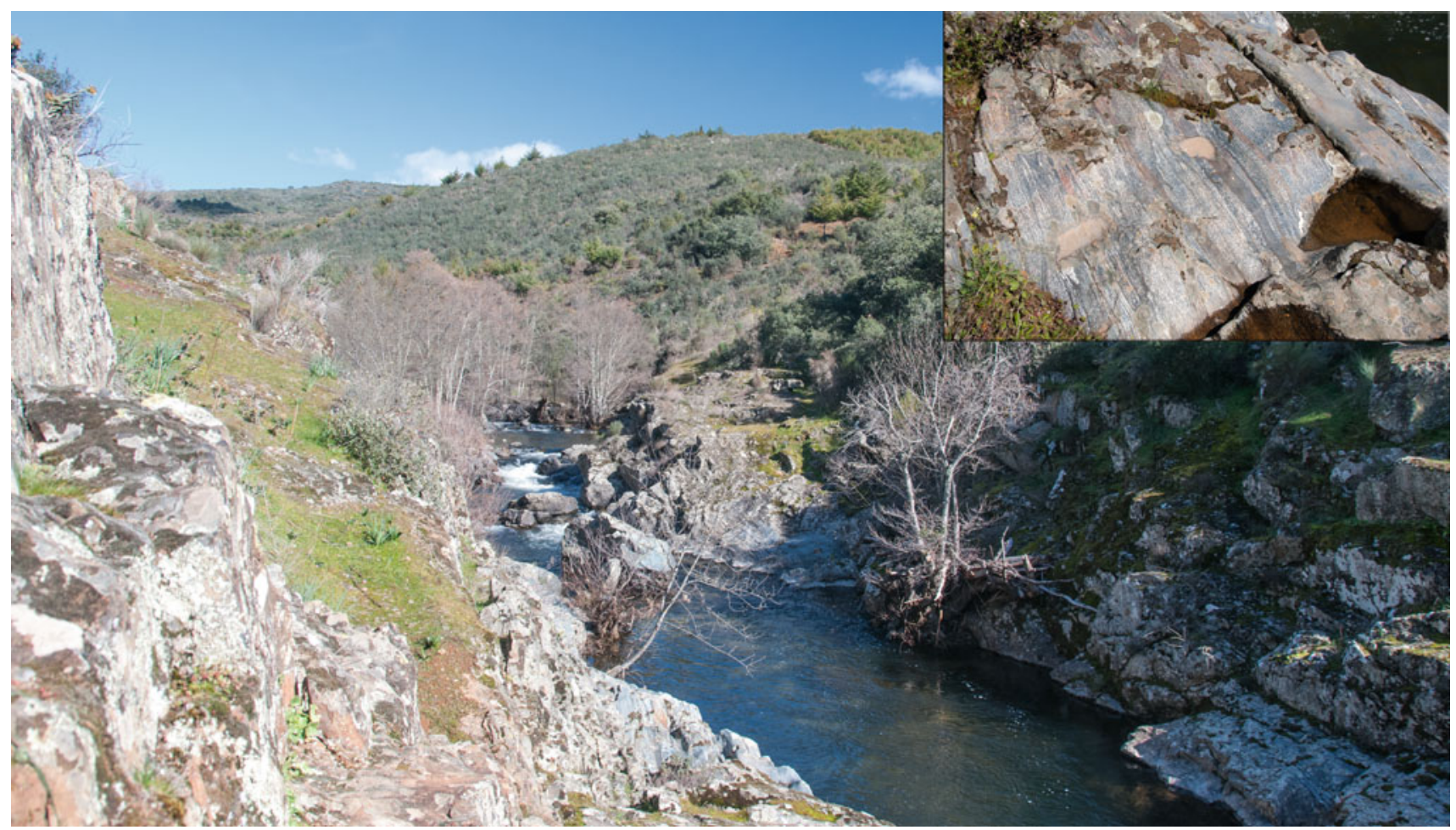

Fig. 25.12 Poço dos Paus geosite has high scientific value attending to the large amount of mafic dikes cropping out at the riversides of the Azibo River (detail in the upper right corner). The scenic value is also considered for geotouristic purposes

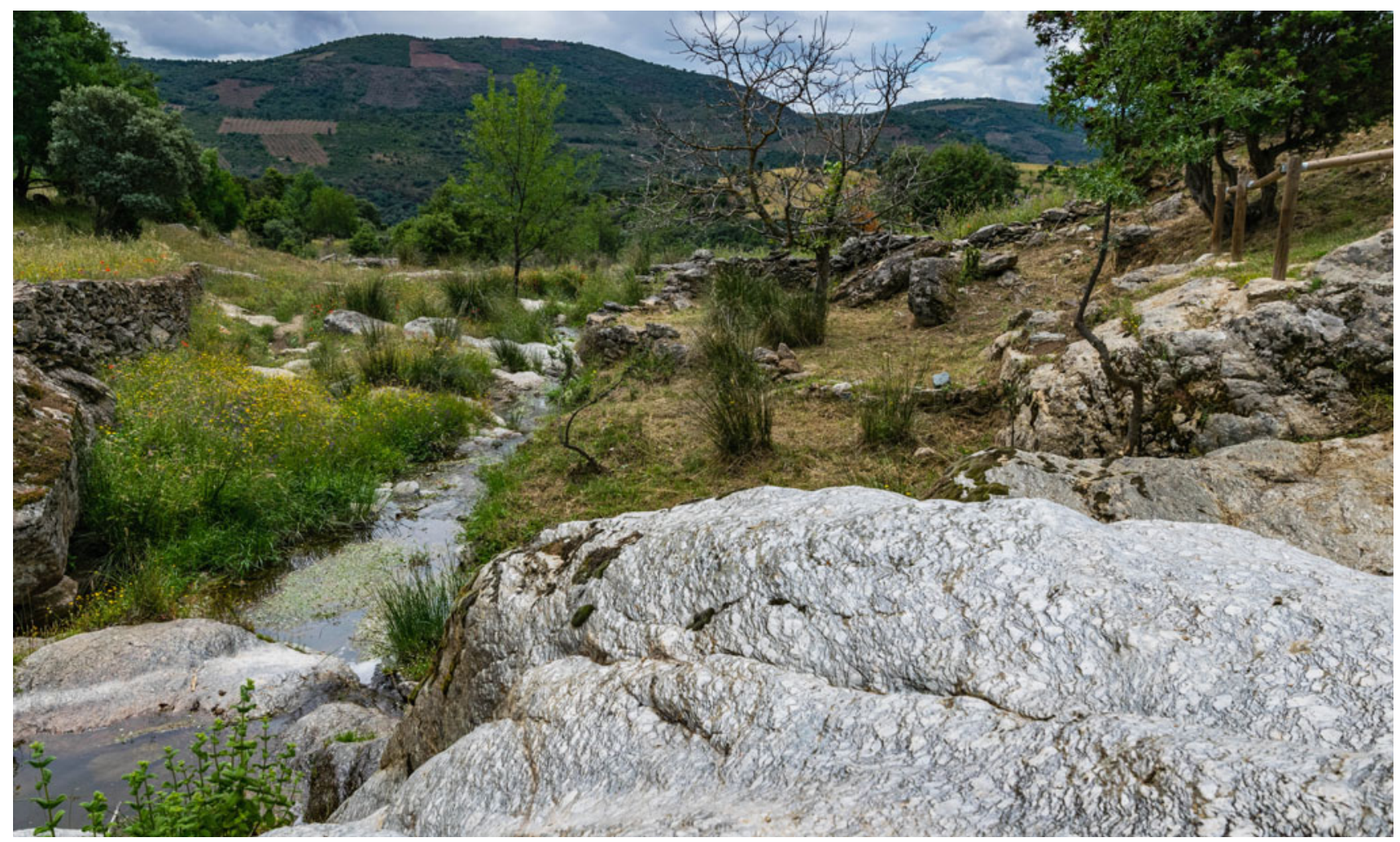

Fig. 25.13 Lagoa Gneiss geosite (photograph Pedro Peixoto) 


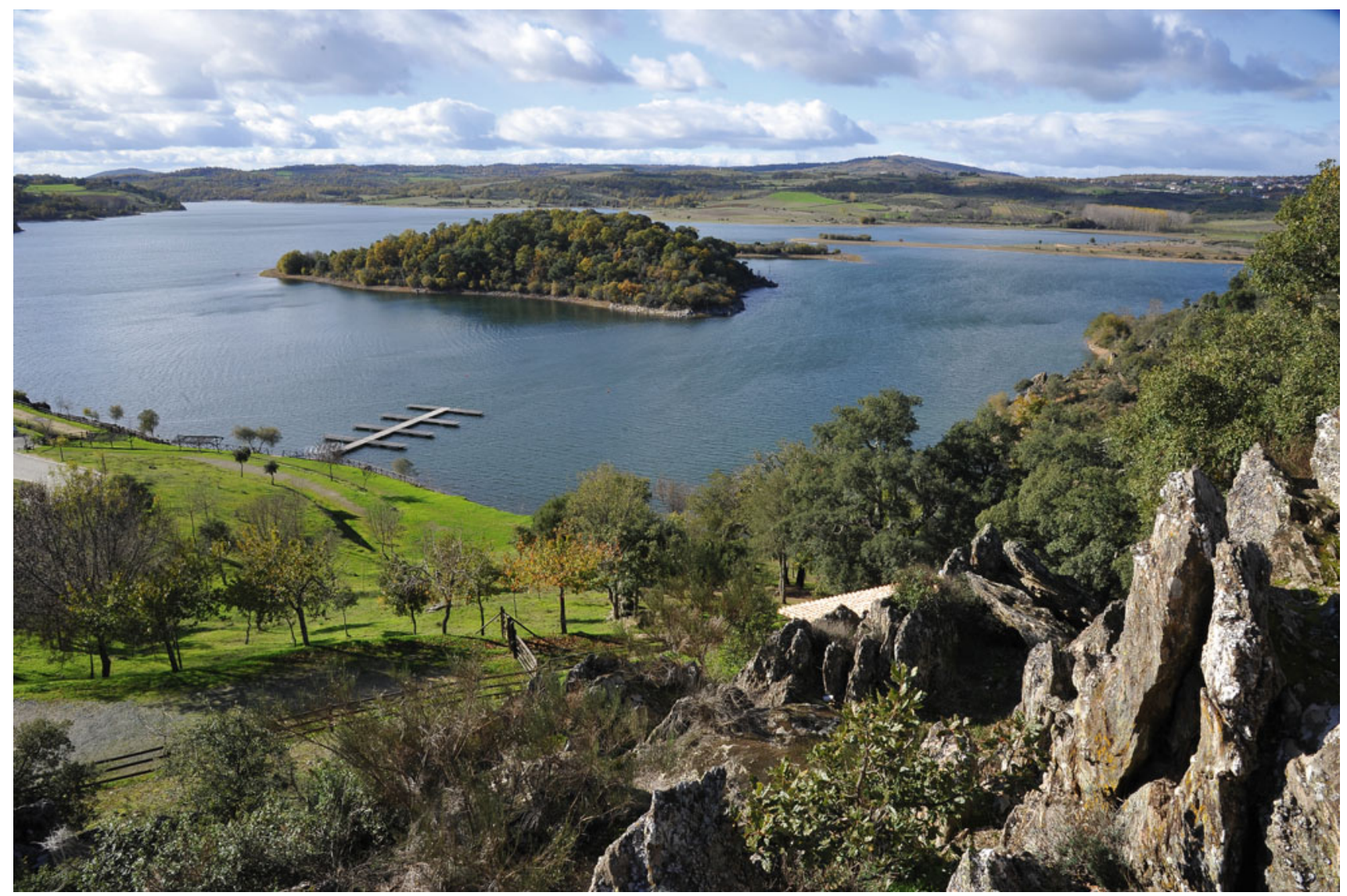

Fig. 25.14 Azibo's Reservoir, a protected area dedicated to biodiversity conservation

mine has served for the exploitation of tungsten and tin, which occur in quartz veins that can still be observed. The visit focuses on the observation of quartz veins with tungsten, on its industrial applications, strong relationship with the World War II and on an outlook to the future.

\section{(f) Limestone of Salselas geosite}

The geosite shows limestones, rare rocks in northern Portugal, that were exploited here in the past. Actually, this is an example of the utilization of a rare geological feature in the region, which constitutes the raw material of lime, produced in furnaces that still persist in the region.

\subsection{Thematic Trails}

The Terras de Cavaleiros Global Geopark offers thematic trails that link several geosites. Three trails are dedicated to the relation between geology, geomorphology and society, natural hazards and Earth's history: i. the trail "Geological resources in the TCG" links several geosites like the Murçós Mine geosite, the Limestone of Salselas geosite, the abandoned talc mine geosite, or the Asbestos geosite, emphasizing the importance of the geological resources to society, ii. the trail "Geological faults and earthquakes in the TCG" links geosites related to active faults and tectonic landforms and iii. the "Morais Ocean" trail covers the theme of the ophiolite sequence, with the geosites presented as exotic occurrences of rocks and seismic discontinuities typical for ocean floor and the Earth's interior settings that rarely can be seen at the surface.

Within the TCG, the Azibo's Reservoir is a protected area dedicated to biodiversity conservation (Fig. 25.14). This area offers a network of pedestrian paths especially dedicated to biodiversity, namely the observation of different types of insects. In addition to other activities and leisure sites, the area was elected the best lake beach in Portugal.

\subsection{Conclusions}

The particularities of the Terras de Cavaleiros Geopark geology and geomorphology support its early recognition as a UNESCO Global Geopark. Besides the geoheritage and the geoconservation issues, the development of the Geopark 
is also supported by the commitment of the municipality, the excellent accessibility, the engagement of the partners, the broad scientific support, as well as by the biodiversity and unique cultural heritage. In the TCG, several infrastructures support scientific research, school visits, recreation and nature sports.

Acknowledgements This work is co-funded by the European Union through the European Regional Development Fund, based on COMPETE 2020 (Programa Operacional da Competitividade e Internacionalização), project ICT (UID/GEO/04683/2013) with reference POCI-01-0145-FEDER-007690 and national funds provided by Fundação para a Ciência e Tecnologia.

\section{References}

Cabral J (1995) Neotectónica em Portugal Continental. Memórias do Instituto Geológico e Mineiro 31:265

Calvo J, Daams R, Morales J, Lopez-Martínez N, Agusti J, Anadon P, Armenteros I, Cabrera L, Civis J, Corrochano A, Diaz-Molina M, Elizaga E, Hoyos M, Martin-Suarez E, Martínez J, Moissenet E, Muñoz A, Pérez-Garcia A, Pérez-Gonzalez A, Portero J, Robles F, Santisteban C, Torres T, Van der Meulen AJ, Vera J, Mein P (1993) Up-to-date Spanish continental Neogene synthesis and paleoclimatic interpretation. Rev Soc Geol Espana 6(3-4):29-40

De Vicente G, Cloetingh S, Muñoz-Martín A, Olaiz A, Stich D, Vegas R, Galindo-Zaldivar J, Fernández-Lozano J (2008) Inversion of moment tensor focal mechanisms for active stresses around microcontinent Iberia: tectonic implications. Tectonics 27:1-22

De Vicente G, Cloetingh S, Van Wees JD, Cunha PP (2011) Tectonic classification of Cenozoic Iberian foreland basins. Tectonophysics 502(1-2):38-61

Ferreira AB (1991) Neotectonics in Northern Portugal. A geomorphological approach. 2. Geomorph N F sup.-Bd 82:73-85

Noronha F, Ferreira N, Marques de Sá C (2006) Rochas granitóides: Caracterização Petrológica e Geoquímica. In: Pereira E (coord) Notícia Explicativa da folha 2 da Carta Geológica de Portugal à escala 1/200000. Instituto Nacional de Engenharia, Tecnologia e Inovação, Lisboa, p 119

Pais J, Cunha P, Pereira DI, Legoinha P, Dias R, Moura D, Silveira AB, Kullberg JC, González-Delgado JA (2012) The Paleogene and Neogene of Western Iberia (Portugal): a Cenozoic record in the European Atlantic Domain. Springer Briefs in Earth Sciences, p 158

Pereira DI (1997) Sedimentologia e estratigrafia do Cenozóico de Trás-os-Montes oriental (NE Portugal). Ph.D., Univ. Minho, p 341

Pereira DI (1998) Enquadramento estratigráfico do Cenozóico de Trás-os-Montes oriental. Comunicações do IGM 84(1):A126-A129

Pereira DI (1999) Terciário de Trás-os-Montes oriental: evolução geomorfológica e sedimentar. Comunicações do IGM 86:213-226

Pereira DI (2006a) Depósitos Cenozóicos. In Pereira E (coord), Notícia Explicativa da Folha 2 da Carta Geológica de Portugal na escala 1:200000, Inst. Geol. Mineiro, pp 43-48

Pereira E (coord) (2006b) Carta Geológica de Portugal à escala 1/200000. Notícia explicativa da Folha 2. Instituto Nacional de Engenharia, Tecnologia e Inovação, Lisboa

Pereira DI, Pereira P (2019) The geomorphological landscape of Trás-os-Montes and Alto Douro. In Vieira G, Zêzere JL, Mora C (eds) Landforms and landscapes of Portugal. World Geomorphological Landscapes series. Springer, Berlin (in this volume)

Pereira DI, Alves MI, Araújo MA, Cunha PP (2000) Estratigrafia e interpretação paleogeográfica do Cenozóico continental do norte de Portugal. Ciências da Terra 14:73-82

Pereira E, Rodrigues J, Castro P (2012) O Maciço de Morais: Terras de Cavaleiros Geopark report

Pereira DI, Pinto B, Marcos S (2013) Terras de Cavaleiros Aspiring Geopark: An outreach strategy based on the typology of visitors. 12th European Geopark Conference extended proceedings

Ribeiro A (2013) A evolução Geodinâmica de Portugal: os ciclos ante-mesozóicos. Geologia de Portugal, Escolar Editora I:11-54

Ribeiro A, Munhá J, Dias R, Mateus A, Pereira E, Ribeiro ML, Fonseca P, Araújo A, Oliveira JT, Romão J, Chaminé H, Coke C, Pedro JC (2007) Geodynamic Evolution of the SW Europe Variscides. Tectonics, 26, Art. No TC6009

Ribeiro A, Pereira E, Dias R (1990) Structure in the NW of the Iberia Peninsula (Alloctonous sequences). In: Dallmeyer RD, Martinez Garcia E (eds) Pre-Mesozoic Geology of Iberia, Springer, Berlin,, pp 220-236 